\title{
Article \\ Mycelia-Assisted Isolation of Non-Host Bacteria Able to Co-Transport Phages
}

\author{
Xin You ${ }^{1}{ }^{\mathbb{D}}$, Niclas Klose ${ }^{1}$, René Kallies ${ }^{1}{ }^{\mathbb{D}}$, Hauke Harms ${ }^{1,2}$, Antonis Chatzinotas ${ }^{1,2,3}$ and Lukas Y. Wick ${ }^{1, * \mathbb{D}}$ \\ 1 Helmholtz Centre for Environmental Research-UFZ, Department of Environmental Microbiology, \\ Permoserstraße 15, 04318 Leipzig, Germany; xin.you@ufz.de (X.Y.); niclas.klose@ufz.de (N.K.); \\ rene.kallies@ufz.de (R.K.); hauke.harms@ufz.de (H.H.); antonis.chatzinotas@ufz.de (A.C.) \\ 2 German Centre for Integrative Biodiversity Research (iDiv) Halle-Jena-Leipzig, Puschstraße 4, \\ 04103 Leipzig, Germany \\ 3 Institute of Biology, Leipzig University, Talstr.33, 04103 Leipzig, Germany \\ * Correspondence: lukas.wick@ufz.de; Tel.: +49-341-235-1316
}

Citation: You, X.; Klose, N.; Kallies, R.; Harms, H.; Chatzinotas, A.; Wick, L.Y. Mycelia-Assisted Isolation of Non-Host Bacteria Able to Co-Transport Phages. Viruses 2022, 14, 195. https://doi.org/10.3390/ v14020195

Academic Editor: Stephen T. Abedon

Received: 8 December 2021 Accepted: 17 January 2022 Published: 20 January 2022

Publisher's Note: MDPI stays neutral with regard to jurisdictional claims in published maps and institutional affiliations.

Copyright: (C) 2022 by the authors. Licensee MDPI, Basel, Switzerland. This article is an open access article distributed under the terms and conditions of the Creative Commons Attribution (CC BY) license (https:// creativecommons.org/licenses/by/ $4.0 /)$

\begin{abstract}
Recent studies have demonstrated that phages can be co-transported with motile nonhost bacteria, thereby enabling their invasion of biofilms and control of biofilm composition. Here, we developed a novel approach to isolate non-host bacteria able to co-transport phages from soil. It is based on the capability of phage-carrying non-host bacteria to move along mycelia out of soil and form colonies in plaques of their co-transported phages. The approach was tested using two model phages of differing surface hydrophobicity, i.e., hydrophobic Escherichia virus T4 (T4) and hydrophilic Pseudoalteromonas phage HS2 (HS2). The phages were mixed into soil and allowed to be transported by soil bacteria along the mycelia of Pythium ultimum. Five phage-carrying bacterial species were isolated (Viridibacillus sp., Enterobacter sp., Serratia sp., Bacillus sp., Janthinobacterium sp.). These bacteria exhibited phage adsorption efficiencies of $\approx 90-95 \%$ for hydrophobic T4 and 30-95\% for hydrophilic HS2. The phage adsorption efficiency of Viridibacillus sp. was $\approx 95 \%$ for both phages and twofold higher than T4-or HS2-adsorption to their respective hosts, qualifying Viridibacillus sp. as a potential super carrier for phages. Our approach offers an effective and target-specific way to identify and isolate phage-carrying bacteria in natural and man-made environments.
\end{abstract}

Keywords: viruses; co-transport; viral adsorption; motile bacteria; hitchhiking

\section{Introduction}

Bacteriophages (also termed phages) have received increasing interest as drivers of microbial ecology [1] and/or as agents to control bacterial biofilms relevant for human health [2,3], food hygiene [4,5], and environmental safety [6,7]. Phages are intrinsically non-motile anti-bacterial agents that typically disperse by diffusion (diffusion $\approx 4 \times$ $\left.10^{-10} \mathrm{~m} \mathrm{~s}^{-1}[8,9]\right)$ or advection to their hosts. Alternatively, phages may also adsorbed to (bio-) surfaces and disperse together with their vectors (e.g., non-host bacteria [10] or invertebrates [11]). At short distances, they may be ejected by explosive cell lysis [12], while phages immobilized e.g., on soil particles can act as set-and-wait predators for dispersing host bacteria in soil $[13,14]$. Hence, phage mobility is strongly influenced by interaction with their surrounding environments. In biofilms, phage mobility is the key determinant of its anti-bacterial efficiency [15] but is often hindered by adsorption to the biofilm extracellular matrix [16-18] (as reviewed by [19]). Using non-host motile bacteria as phage carriers, recent studies have demonstrated that lytic phages can be delivered to host biofilms by co-transport with motile bacteria [10] and exert anti-microbial effects on biofilm-dwelling bacteria $[10,20,21]$. Thus, co-transported phages may serve as "weapons" [22] and allow invasion of their carrier bacteria into host biofilms [10]. Phage co-transport with motile bacteria may also simulate other biological invasion processes (e.g., pests or pathogens being co-transported by other species [23-25]) and be useful in 
models challenging new hypotheses regarding biological invasion $[10,26]$. Although phage adsorption to environmental bacteria has been well described by multiple methods (e.g., metagenomic analysis [20], AdsorpSeq [27], fluorescent labeling [21], and cryo-electron microscopy [28]), few attempts have been made to isolate culturable phage-carrying bacteria as potential tools for challenging invasion hypothesis in microbial ecology or as phageassociated biofilm control agents in biotechnology.

Mycelia have been found as scaffolds for bacterial translocation ("fungal highway" [29]) in manifold microbial habitats including soil [29-32], plants [33,34], food [35,36], and human tissues [37]. Among such habitats, soil is a major reservoir for bacterial genetic diversity [38] and harbors abundant motile bacteria [30]. Motile soil bacteria are well-known vectors for inter-microbial co-transport (e.g., reviewed by [39]). However, much less is known about their ability to co-transport phages. Although often enabling bacterial dispersal through water-unsaturated zones, mycelia can retain the waterborne transport of phages [40,41]. Phage adsorption to (bio-)surfaces is mainly driven by the properties (e.g., hydrophobicity $[40,42,43]$, surface charge [44]) of the phages and their interacting surfaces $[20,40,45,46]$, phage morphology, and size [47] as well as environmental factors [48,49].

Here, we developed a novel laboratory approach to isolate non-host bacteria able to co-transport phages from soil. It is based on the observation that phages can interact with non-host bacteria and that phage-carrying bacteria can move along mycelia out of soil and develop separable colonies in plaques formed by their co-transported phages in host biofilms. We chose two model phages of differing surface hydrophobicity (i.e., hydrophobic Escherichia virus T4 (T4) and hydrophilic Pseudoalteromonas phage HS2 (HS2)), as hydrophobic phages are often found to be more adsorptive to (bio-)surfaces than hydrophilic phages [40,43]. To validate our system, we first mixed T4 or HS2 with gfp-labeled Pseudomonas putida KT2440 as inoculum and screened for plaques containing green fluorescent colonies that formed during the mycelia-assisted colonization of phage-carrying P. putida KT2440 in biofilms of the respective phages' host strains. In a second step, we mixed model phages into fresh soil and let phage-carrying soil bacteria move out of the soil along mycelia and utilize phages as "weapons" to form colonies for direct isolation. We thereby isolated five bacterial strains that can co-transport phages (i.e., Viridibacillus sp., Enterobacter sp., Serratia sp., Bacillus sp. Janthinobacterium sp.) with the Viridibacillus sp. being a super carrier $(\approx 95 \%$ adsorption efficiency for both hydrophobic T4 and hydrophilic HS2). Our approach offers an effective and target-specific way for the isolation of phage-carrying non-host bacteria. Such isolates do not only improve our knowledge on the transport and ecology of phages in natural (e.g., soil) ecosystem, but they may also be applied as biotechnological tools (together with phages) to control biofilms in natural and engineered ecosystems.

\section{Materials and Methods}

\subsection{Strains, Growth Conditions, and Phage Enumeration}

Two well-characterized lytic phages of distinct surface hydrophobicity were used as model phages (cf. Table S1), i.e., Escherichia virus T4 (NCBI:txid2681598) and Pseudoalteromonas phage HS2 [50] (NCBI:txid1348399). T4 has a hydrophobic surface with a water contact angle $\left(\theta_{\mathrm{w}}\right)$ of $\approx 95^{\circ}$, while HS2 is less hydrophobic $\left(\theta_{\mathrm{w}} \approx 40^{\circ}\right)$ [47,51] (cf. Table S1). Both phages were propagated with their hosts using a liquid propagation method [52]. In short, infectious phages were added to host cultures (cf. Table S3) at an early exponential phase $\left(\mathrm{OD}_{600} \approx 0.1\right)$ to have a multiplicity of infection of $\approx 0.1$. The suspensions were further incubated at $22{ }^{\circ} \mathrm{C}$ for Pseudoalteromonas H13-15 and $30{ }^{\circ} \mathrm{C}$ for E. coli with $125 \mathrm{rpm}$ until complete bacterial lysis was observed after 6-8 h of co-incubation. The lysed bacterial culture containing the propagated phages was further purified by centrifugation and filtration, as described earlier [47]. Freshly propagated phage solutions contained $10^{11}-10^{12}$ plaque-forming units (PFUs) $\mathrm{mL}^{-1}$ and were stored at $4{ }^{\circ} \mathrm{C}$ as stock solutions. PFU enumeration was done using a whole-plate plaque assay as detailed earlier [53], allowing the double-layer counting plates to be incubated overnight at RT $\left(30^{\circ} \mathrm{C}\right.$ for T4). 
The gfp-labeled Pseudomonas putida KT2440 (P. putida KT2440) was used as a model phagecarrying bacterium to validate our microcosm setup for phage-bacterial co-transport. The strain was kindly provided by Arnaud Dechesne (Technical University of Denmark). It was cultivated in LB medium with $150 \mathrm{rpm}$ at $30^{\circ} \mathrm{C}$. The hyphae of the oomycete Pythium ultimum (P. ultimum) were used as model dispersal networks, as they are fast growing and allow for efficient bacterial dispersal [29]. P. ultimum was cultivated on potato dextrose agar (PDA) at room temperature (RT; approximately $22{ }^{\circ} \mathrm{C}$ ) [54].

\subsection{Description of the Microcosm Setup}

To isolate phage-carrying bacteria, we developed a microbial model system on standard Petri dishes (diameter, $\varnothing=90 \mathrm{~mm}$ ) allowing phage-carrying bacteria to disperse along mycelia and form colonies in plaques of their co-transported phages for direct isolation. The model system consisted of two agar patches: an inner circular agar patch (PDA, $1.5 \%$ agar $(w / v), \varnothing=12 \mathrm{~mm})$ and an outer donut-shaped host agar ring $(\varnothing=14-90 \mathrm{~mm})$ that left a $2 \mathrm{~mm}$ airgap to the inner circle (Figures $1 \mathrm{a}$ and $2 \mathrm{a}$ ). The outer ring consisted of a double-layered agar: a top layer $(0.5 \%$ agar $(w / v), \mathrm{h}=1 \mathrm{~mm})$ inoculated with the

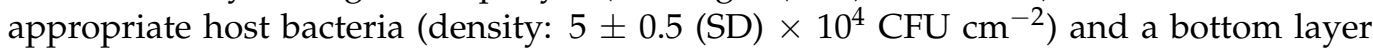
$(1.5 \%$ agar $(w / v), \mathrm{h}=0.5 \mathrm{~cm})$ of the respective medium for phage host (cf. Table S3). The inner agar patch was pre-inoculated with P. ultimum 3-4 days prior to the final assembly of the microcosms, allowing $>0.5 \mathrm{~cm}$ hyphal growth. The host-inoculated agar ring was freshly prepared using host bacterial culture $\left(\mathrm{OD}_{600} \approx 0.4-0.6\right)$, as detailed by [55] and placed with around an inner agar patch with pre-grown P. ultimum, bridging the airgap on the day of the experiment. Assembled microcosms were covered with lids to minimize moisture loss before inoculation. For more details, cf. the extended protocol for microcosm assembly in the Supplementary Materials.
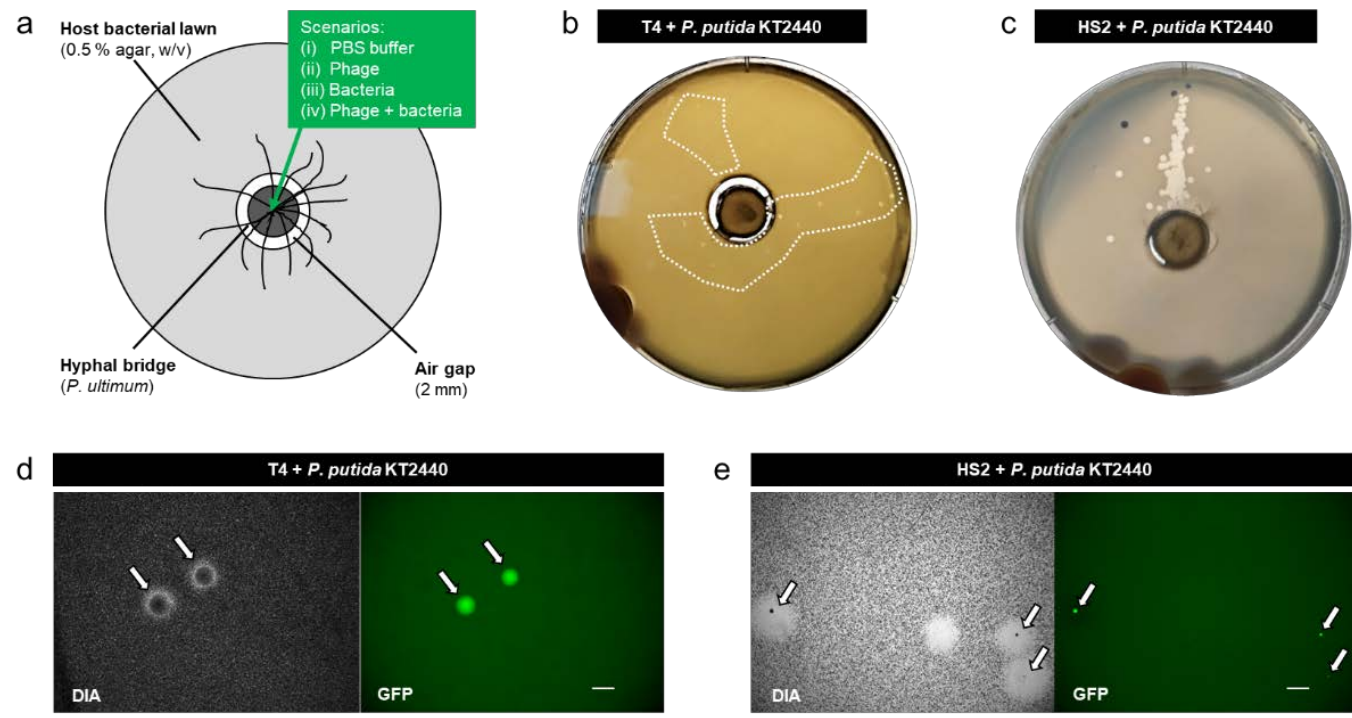

Figure 1. Schematic view of the microcosm used to isolate phage-carrying non-host bacteria (a), representative photographs of the microcosms after $1 \mathrm{~d}$ in the presence of T4 + P. putida KT2440 (b), and HS2 + P. putida KT2440; The dashed inserts in Figure 1b,c depict areas on plates containing turbid plaques.(c). Figure 1 (d). Representative micrograph of fluorescent colonies of co-transported P. putida KT2440 (indicated by white arrows and shown in green color under gfp channel) in the middle of turbid plaques of T4 (d) and HS2 (e) observed after $1 \mathrm{~d}$ on the respective host bacterial lawns. Scale bars reflect a length of $1 \mathrm{~mm}$. 

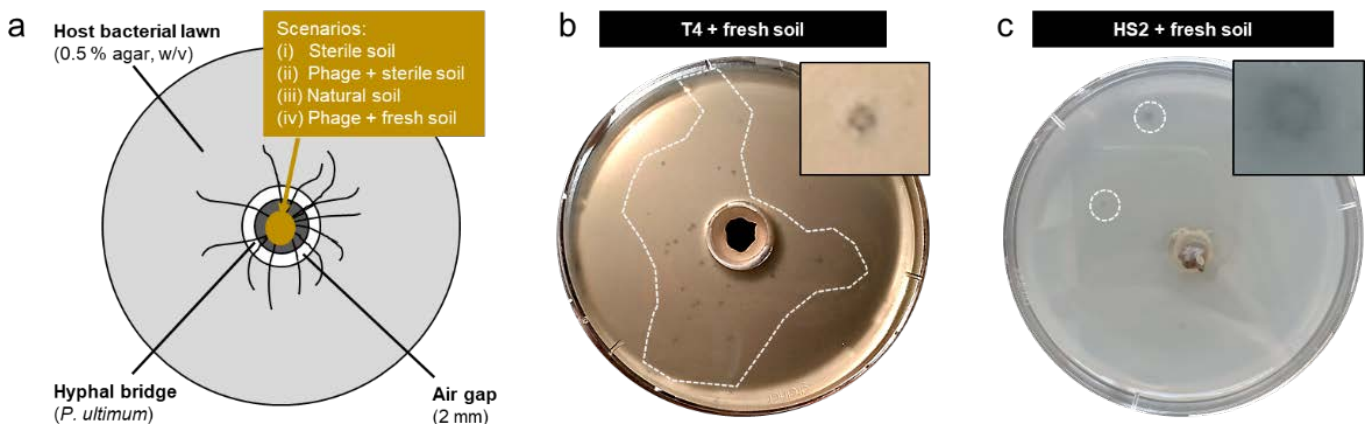

Figure 2. Schematic view of the microcosm used to isolate phage carrying non-host bacteria from fresh soil (a) and representative photographs of the microcosms after $1 \mathrm{~d}$ from "T4 in fresh soil" (b; cf. Figure S2 for control scenarios) and "HS2 in fresh soil" co-transport experiments (c). The dashed inserts in Figure 2b,c depict areas on plates containing turbid plaques.

\subsection{Validation of the Setup Using gfp-Labeled Model Bacteria}

To test the suitability of the microcosm, we used flagellated and gfp-labeled P. putida KT2440 as carriers for the co-transport of T4 and HS2. This strain has been used as a model organism for bacterial dispersal along mycelia [56,57] and was shown to co-transport phages along mycelia into biofilms [10]. It can be recognized and visualized in mixed communities by its gfp label [58]. Four different inoculation scenarios were tested by adding $2.5 \mu \mathrm{L}$ of phosphate-buffered saline (PBS, $100 \mathrm{mM}$, cf. Table S3) containing: (i) no bacteria and no phages (PBS), (ii) T4 or HS2 phages only, (iii) P. putida KT2440 only, or (iv) P. putida KT2440 in combination with T4 or HS2. The respective inocula (i.e., $\approx 10^{8}$ bacteria or $\approx 1.5 \times 10^{6}$ phages) were placed in the center of the inner agar patch, and each scenario was performed in 4-8 replicates. To prepare the inoculum of scenario (iv), T4 or HS2 $\left(\approx 6 \times 10^{9} \mathrm{PFU} \mathrm{mL}{ }^{-1}\right)$ was co-incubated with P. putida $\mathrm{KT} 2440\left(\approx 8 \times 10^{9}\right.$ cells $\left.\mathrm{mL}^{-1}\right)$ in PBS at RT for $1 \mathrm{~h}$ in a $15 \mathrm{~mL}$ centrifuge tube at $100 \mathrm{rpm}$. The suspension was subsequently centrifuged $\left(8000 \times \mathrm{g}\right.$ for $10 \mathrm{~min}$ at $\left.4{ }^{\circ} \mathrm{C}\right)$ to discard free phages in the supernatant. The remaining pellet containing bacteria and adsorbed phages was resuspended in PBS by pipetting up and down and gently inverting the tube $4-6$ times to obtain an $\mathrm{OD}_{600} \approx 2$. Then, the suspension was centrifuged $\left(8000 \times g\right.$ for $10 \mathrm{~min}$ at $\left.4{ }^{\circ} \mathrm{C}\right)$, the supernatant was discarded, and the washed pellet was re-suspended in PBS to obtain a concentrated inoculum of calculated $\mathrm{OD}_{600}$ of $\approx 50$. After inoculation, the Petri dishes were sealed with Parafilm (Bemis Company, Inc., Nina, WI, USA), placed in a plastic container, and incubated at $22{ }^{\circ} \mathrm{C}$ (or at $30^{\circ} \mathrm{C}$ for T4) in the dark. After 1 day of incubation, the plates were screened for plaques and the formation of P. putida KT2440 colonies. Colonies of gfp-tagged P. putida KT2440 were confirmed with an epifluorescence microscope equipped with a black-and-white camera (AZ 100 Multizoom; Nikon, Amsterdam, The Netherlands) under the gfp channel using Nikon's NIS Elements software. Plaques were also purified and tested against the respective hosts by performing plaque-forming assays (either E. coli or Pseudoalteromonas H13-15) to confirm their origin.

\subsection{Isolation and Cultivation of Phage-Carrier Bacteria from Soil}

To isolate phage-carrier bacteria from soil, phage-treated soil as inoculum was placed in the center of the inner agar patch. To do this, fresh topsoil $(5-20 \mathrm{~cm}$ below the litter layer) was collected from a forest site (UTM: E 598830, N 5662818) in the Hainich Critical Zone Exploratory (Hainich CZE) in Thuringia, Germany and sieved through a $1 \mathrm{~mm}$ mesh. Then, $5 \mathrm{~g}$ of the sieved soil was placed into a $15 \mathrm{~mL}$ conical centrifuge tube together with $1 \mathrm{~mL}$ of a phage stock solution $\left(\approx 10^{10} \mathrm{PFU} \mathrm{mL}{ }^{-1}\right)$ and $9 \mathrm{~mL}$ PBS to form a phage-soil suspension. The phage-soil suspension was further vortexed for $20 \mathrm{~min}$ at maximum speed and incubated for $3 \mathrm{~h}$ at $125 \mathrm{rpm}$ (RT) to ensure the sufficient adsorption of phages to soil bacteria. After incubation, the phage-soil suspension was centrifuged $(8000 \times g$ for $10 \mathrm{~min}$ at $4{ }^{\circ} \mathrm{C}$ ), and free phages in the supernatant were discarded. A portion of the 
remaining pellet $(\varnothing<8 \mathrm{~mm})$ containing soil and soil bacteria with adsorbed phages was directly scooped out and placed on the round agar patch. Inocula with (i) (autoclaved) sterile soil, (ii) T4 or HS2 and sterile soil, and (iii) T4 or HS2 and fresh soil were tested. Each scenario was performed in 4-8 replicates. Sterile soil was obtained by twice autoclaving at $120{ }^{\circ} \mathrm{C}$ for $1 \mathrm{~h}$, leaving about one day between the two sterilization steps. After inoculation, the Petri dishes were sealed with Parafilm, placed in a plastic container, and incubated at $22{ }^{\circ} \mathrm{C}$ (or at $30{ }^{\circ} \mathrm{C}$ for T4) in the dark. After 1 day, the plates were screened for plaques and colonies of soil bacteria (expected to appear in the plaques). Screened colonies (40 in total) in phage plaques were streaked by an inoculation loop and transferred on a new plate to form single colonies. Representative colonies of different morphologies were picked and purified by transferring to new plates for three times. They were further tested for phage susceptibility (spot test as described by [59]) to exclude potential contaminations from the phage host bacteria.

\subsection{Identification and Characterization of Phage-Carrying Bacteria}

The taxonomic affiliations of phage-insusceptible isolates ( 23 in total) were determined by PCR amplification of bacterial $16 \mathrm{~S}$ rRNA gene fragments using the universal primer pairs 27F/1492R [60,61]. Paired-end sequencing of the obtained PCR product was done by GATC services (Eurofins, Ebersberg, Germany) using primers 27F/1492R (Biomers, Ulm, Germany). Isolates showing $>99.9 \%$ identical sequences were classified as identical. Sequences of different bacteria were assigned to their closest reference relative using BLASTn [62] and cross-referenced with SILVA Incremental Aligner [63]. After taxonomic identification, the surface properties of all bacteria isolates were characterized by measuring $\theta_{\mathrm{w}}$ and approximating their zeta potentials $(\zeta)$, as described previously $[47,64]$. Swimming and swarming motility assays were also performed as detailed by $[56,65]$ to evaluate bacterial motility.

\subsection{Phage Adsorption Assays}

To determine the phage adsorption efficiencies of the soil isolates, phage adsorption assays were performed. All adsorption assays were performed at phage-to-bacteria ratios of 1 in triplicates, as described earlier [66]. In brief, suspensions of bacteria and phages $\left(\approx 10^{7} \mathrm{CFU} / \mathrm{PFU} \mathrm{mL}{ }^{-1}\right)$ were incubated in PBS at $22^{\circ} \mathrm{C}$ for $1 \mathrm{~h}$ and centrifuged at $8000 \times g$ at $4{ }^{\circ} \mathrm{C}$ to pellet bacteria and adsorbed phages. For experiments comparing phage adsorption efficiencies to host and non-host bacteria (i.e., Viridibacillus sp.), suspensions of bacteria and phages were also incubated for $1 \mathrm{~min}, 5 \mathrm{~min}$, and $15 \mathrm{~min}$ before centrifugation and evaluation. Amounts of adsorbed phages were estimated by the loss of free phages in the supernatant after centrifugation; i.e., phage adsorption (\%) was calculated by the ratio of adsorbed phages to total phages prior to centrifugation. A phage-only control was included to determine adsorption efficiency. The colloidal stability of phage-only controls could be maintained to $\approx 2 \mathrm{~h}$ at RT and was not influenced by the centrifugation process (cf. Table S1).

\section{Results}

\subsection{Microcosms for Isolation of Non-Host Bacteria Able to Co-Transport Phages}

Microcosms were established, allowing the dispersal of phage-carrying bacteria along mycelia to a lawn of host bacteria that was spatially separated by a $2 \mathrm{~mm}$ air gap (Figure 1a). Consistent with our previous findings (e.g., $[10,29,67])$, the microcosm without fungal mycelia showed no transport of bacteria and/or phages over the airgap. We evaluated the transport of bacteria and/or phages along mycelia in four scenarios: (i) PBS, (ii) T4 or HS2, (iii) P. putida KT2440, and (iv) T4 + P. putida KT2440 or HS2 + P. putida KT2440. No plaques were observed in scenario (i) and scenario (ii) at any time (Figure S1), with the latter indicating no transport of phages along mycelia in the absence of bacteria. After $18 \mathrm{~h}$ and in accordance with our previous findings (e.g., [10,56]), we observed a dispersal of P. putida KT2440 along the hyphae (Figure S3a) in scenario (iii). However, no colonies of 
P. putida KT2440 were found in the host bacterial lawn on the outer agar ring, suggesting that P. putida KT 2440 was able to transport along mycelia but not able to establish in the pre-established lawn of host bacteria. When P. putida KT2440 had pre-adsorbed phages (scenario iv), we observed turbid plaques with distinct gfp-expressing colonies in the host bacterial lawns (Figure 1b,c), suggesting the successful co-transport and colonization of P. putida KT2440 in phage plaques (Figure 1d,e). Such turbid plaques were not observed at any time in our control scenarios (i), (ii), and (iii). Due to the small plaque size of T4, the turbid plaques of co-transported T4 and P. putida KT2440 were only visible on day 1. After that, P. putida KT2440 overgrew the area of the plaques as visualized by epifluorescence microscopy (Figure S3). Plaques formed by HS2 in Pseudoalteromonas bacterial lawns were bigger than T4 plaques (Figure 1b,c). Although this provided more space for P. putida KT2440, colonization with gfp-forming colonies was less explicit (Figures 1e and S3), which was likely due to unfavorable growth conditions for strain KT2440 in the high-salinity Pseudoalteromonas medium (Table S3).

\subsection{Isolation of Phage-Carrying Non-Host Bacteria from Soil}

After validation of the system, we aimed to isolate phage-carrying bacteria from a pristine forest soil. To do so, we applied four different scenarios: (i) sterile soil, (ii) T4 or HS2 in sterile soil, (iii) fresh soil with no T4 or HS2, and (iv) T4 or HS2 in fresh soil (Figure 2a). No plaques or clearly distinguishable colonies were observed in scenarios (i), (ii), and (iii) at any time (Figure S2). However, when fresh soil had been augmented with phages (i.e., T4 or HS2), we observed turbid plaques with clearly separable colonies in lawns of host bacteria with high numbers of turbid plaques with T4 (Figure $2 b$ ) and only a few plaques with HS2 (Figure 2c). We conducted the "T4 in fresh soil" experiments using two more media suitable for E. coli (LB and R2A, cf. Table S3) to expand the range of soil bacteria able to establish in E. coli-cleared plaques. In total, we isolated 23 phage-insusceptible colonies that could be attributed to five distinct bacterial genera by $16 \mathrm{~S}$ rRNA gene analysis: Enterobacter sp. and Serratia sp. from T4 plaques on DSM544; Viridibacillus sp. from T4 plaques on LB; Janthinobacterium sp. from T4 plaques on R2A; and Bacillus sp. from HS2 plaques on ZoBell (Table 1). We observed a clear influence of the bacterial growth medium on the isolates. For instance, the use of LB or R2A instead of DSM544 in T4 experiments resulted in the successful isolation of two additional phage-carrying bacteria (i.e., Viridibacillus sp. and Janthinobacterium sp., Table 1).

Table 1. Origin and characterization of phage-carrying bacteria isolated from forest soil.

\begin{tabular}{|c|c|c|c|c|c|}
\hline \multicolumn{2}{|c|}{ Bacterial Isolates } & \multicolumn{2}{|c|}{ Phys.-Chem. Surface Properties } & \multicolumn{2}{|c|}{ Motility ${ }^{f}$} \\
\hline $\begin{array}{l}\text { Co-transported phage } \\
\text { (isolation medium) }\end{array}$ & $\begin{array}{c}\text { Next related sequence } \\
\text { in NCBI } \\
(\% \text { similarity; Gram }+/-)\end{array}$ & $\begin{array}{l}\text { Zeta potential } \\
\qquad(\zeta, \mathrm{mV})\end{array}$ & $\begin{array}{c}\text { Contact angle } \\
\left(\theta_{w}, \text { degree }\right)\end{array}$ & $\begin{array}{l}\text { Swimming } \\
\left(\varnothing, \mathrm{mm} \mathrm{d}^{-1}\right)\end{array}$ & $\begin{array}{l}\text { Swarming } \\
\left(\varnothing, \mathrm{mm} \mathrm{d}^{-1}\right)\end{array}$ \\
\hline $\begin{array}{c}\mathrm{T} 4 \\
\text { (DSM544) }\end{array}$ & $\begin{array}{c}\text { Serratia sp. }{ }^{a} \\
(99.80 \% ; \text { Gram }-)\end{array}$ & $-33 \pm 1$ & $59 \pm 3$ & $77 \pm 5$ & $23 \pm 1$ \\
\hline $\begin{array}{c}\mathrm{T} 4 \\
\text { (DSM544) }\end{array}$ & $\begin{array}{l}\text { Enterobacter sp. }{ }^{\text {b }} \\
(99.86 \% ; \text { Gram }-)\end{array}$ & $-13 \pm 0$ & $37 \pm 2$ & $86 \pm 2$ & $35 \pm 2$ \\
\hline $\begin{array}{c}\mathrm{T} 4 \\
(\mathrm{LB})\end{array}$ & $\begin{array}{l}\text { Viridibacillus sp. }{ }^{c} \\
(99.93 \% \text {; Gram }+)\end{array}$ & $-23 \pm 2$ & $84 \pm 2$ & $85 \pm 1$ & $28 \pm 3$ \\
\hline $\begin{array}{c}\mathrm{T} 4 \\
(\mathrm{R} 2 \mathrm{~A})\end{array}$ & $\begin{array}{c}\text { Janthinobacterium sp. }{ }^{\mathrm{d}} \\
(99.93 \% \text {; Gram -) }\end{array}$ & $-14 \pm 1$ & $62 \pm 6$ & $28 \pm 1$ & - \\
\hline $\begin{array}{c}\text { HS2 } \\
\text { (ZoBell) }\end{array}$ & $\begin{array}{c}\text { Bacillus sp. }{ }^{\mathrm{e}} \\
(98.90 \% \text {; Gram }+)\end{array}$ & $-11 \pm 1$ & $42 \pm 7$ & $7 \pm 1$ & - \\
\hline
\end{tabular}

a-e NCBI accession numbers: ${ }^{\mathrm{a}} \mathrm{MT} 631995,{ }^{\mathrm{b}} \mathrm{CP} 011591,{ }^{\mathrm{c}} \mathrm{MH} 669125,{ }^{\mathrm{d}}$ MF774161, ${ }^{\mathrm{e}}$ MW181146; ${ }^{\mathrm{f}}$ Motility was estimated by the average bacterial displacement in diameter $(\mathrm{mm})$ per day $\left(\mathrm{d}^{-1}\right)$ on swimming/swarming plates after incubation for $48 \mathrm{~h}$ at RT. For fast swimming isolates, only displacement within $24 \mathrm{~h}$ was used for estimation. 


\subsection{Characterization of Phage-Carrying Isolates}

The five isolates were further tested for their swimming and swarming motility, their physicochemical surface properties (as drivers of the strength of colloidal interactions [47]), and their efficiency to adsorb hydrophobic T4 and less hydrophobic HS2, respectively.

All bacteria were negatively charged with only slightly varying zeta potentials $(-11 \mathrm{mV}$ $<\zeta<-33 \mathrm{mV}$; Table 1). However, Viridibacillus sp. was significantly more hydrophobic $\left(\theta \mathrm{w} \approx 84^{\circ}\right)$ than the other isolates $\left(37^{\circ}<\theta_{\mathrm{w}}<62^{\circ}\right.$, Table 1$)$ and, hence, prone to strong interactions with other colloidal particles. Viridibacillus sp., Enterobacter sp., and Serratia sp. showed high swimming $\left(\varnothing>77 \mathrm{~mm} \mathrm{~d}^{-1}\right)$ and swarming $\left(\varnothing>19 \mathrm{~mm} \mathrm{~d}^{-1}\right)$ motility, while Janthinobacterium sp. and Bacillus sp. only exhibited weak $\left(\varnothing \sim 7 \mathrm{~mm} \mathrm{~d}^{-1}\right)$ to intermediate $\left(\varnothing \sim 28 \mathrm{~mm} \mathrm{~d}^{-1}\right)$ swimming motility. We observed high adsorption efficiencies (88-96\%) of hydrophobic T4 to all five isolates (Figure 3a). Apart from Viridibacillus sp. ( $\approx 95 \%)$, the adsorption efficiencies of less hydrophobic HS2 were generally lower (30-52\%, Figure 3) compared to the more hydrophobic T4. Given the efficient adsorption of T4 and HS2 to Viridibacillus sp., we further compared the adsorption kinetics of T4 and HS2 to their respective hosts with their adsorption to Viridibacillus sp. As shown in Figure 3b,c, adsorption by host bacteria and non-host Viridibacillus sp. both followed pseudo-first-order kinetics [68]. Phage adsorption to non-host Viridibacillus sp. thereby was approximately three times faster than to the respective phage hosts (c.f. Table S2), suggesting a surprisingly more efficient adsorption of T4 and HS2 to the non-host Viridibacillus strain.

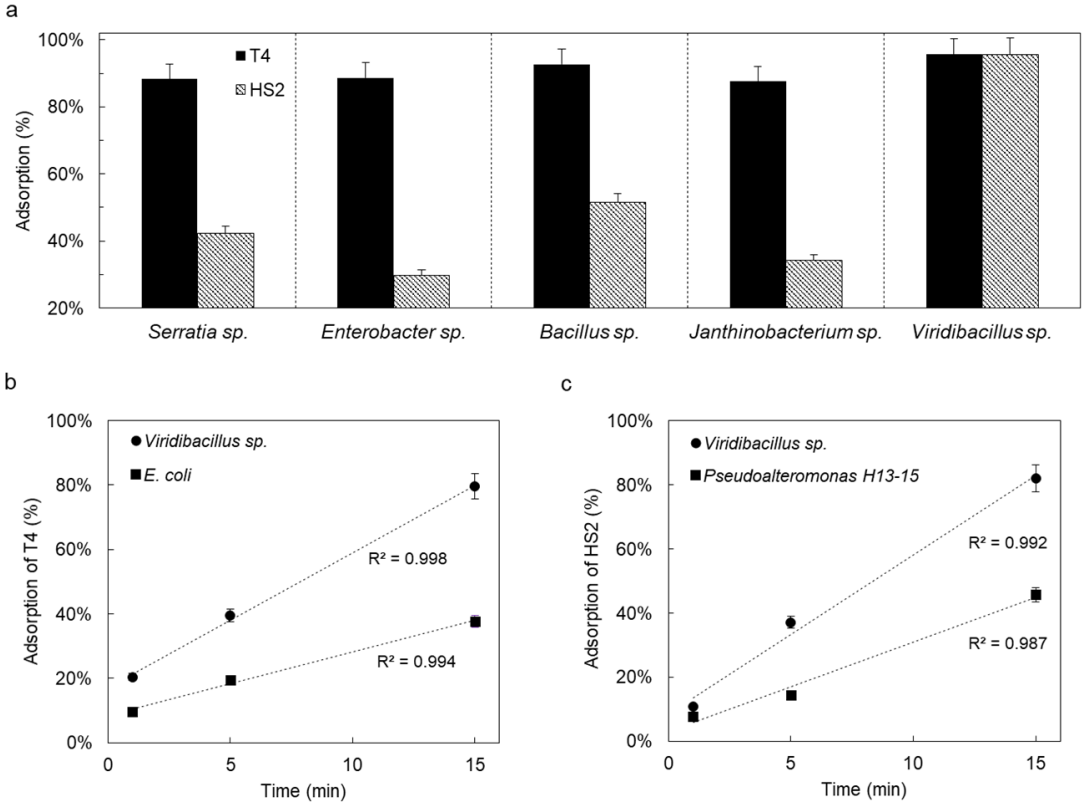

Figure 3. Phage adsorption efficiency (\%) to isolated phage-carrying bacterial isolates (a) and comparison of time-dependent adsorption efficiencies of T4 (b) and HS2 (c) to Viridibacillus sp. and their respective hosts.

\section{Discussion}

\subsection{Mycelia-Assisted Isolation of Non-Host Bacteria Able to Co-Transport Phages}

Although mycelia are well-described logistic networks for bacterial dispersal ("fungal highways" [29]), little is known about their effects on phage transport or phage-bacterial cotransport, even though such knowledge may help to resolve bacterial population dynamics in the hyphosphere [33,69] and put forward the hyphosphere as a model system to study biological invasions [10]. Here, we hypothesized that non-host bacteria can "pick up" phages and carry them along while dispersing along mycelia; this can be used for the targeted isolation of motile bacteria able to efficiently co-transport phages. Our hypothesis is based on previous knowledge on (i) the role of hyphae as conduits for bacterial dispersal 
(e.g., [29,31,35,67]), the observation that bacteria may serve as carriers of phages [20,70,71], and (iii) that co-transport of phages promotes the bacterial colonization of alien habitats (e.g., occupied by the phage's hosts) $[10,20,22,72]$. In order to challenge our hypothesis, we prepared laboratory microcosms for selective mycelia-assisted isolation of phage-carrying bacteria and performed various control experiments. In the presence of mycelia yet in the absence of bacteria (scenario ii; cf. Results section), no plaques were observed in the spatially separated host bacterial lawn (Figure S1), suggesting an inefficient diffusion of phages along hyphae [9] or even hyphal phage retention [40,41]. Thus, mycelia played a decisive role for the bacterial co-transport of phages over airgaps. This is instrumental for the isolation of phage-carrying bacteria, as the sequential transport of (first) phage and (then) bacteria or co-infection $[73,74]$ of non-interacting phages and bacteria would also lead to similar invasion effects into host biofilms. As biofilms typically are robust against colonization by competitors [10,20], we did not observe the colonization of transported P. putida KT2440 (validation experiment) or soil bacteria in the absence of adsorbed phages (Figures S1 and S2). In the presence of T4 or HS2 phages, both P. putida KT2440 and soil bacteria were able to colonize and grow in their respective host bacterial lawn (Figures $1 b, c$ and $2 b, c)$ in competitor-free locations (i.e., plaques created by phages). Thus, mycelia-assisted transport allows isolating motile bacteria that can efficiently adsorb phages (Figure 3) and maintain their infectivity (Figures $1 b, c$ and $2 b, c)$. As hyphae of P. ultimum unevenly bridged the air gap, we speculate that such irregular hyphal distribution may have influenced the transport of the bacterial shuttles and, hence, the observed distribution of plaques (e.g., Figure 1c) on the outer agar ring. Not all mycelial organisms may be used for mycelia-assisted isolation, as some fungi are known to antagonistically interact with bacteria [32]. We chose mycelia of P. ultimum, as they are hydrophilic [29] and known to be good dispersal networks for bacteria $[10,29,75]$, exhibiting little negative interactions with bacteria. Mycelia that are known to be inhibited by phages, e.g., Candida albicans or Aspergillus fumigatus that exhibit inhibited growth in the presence of Pseudomonas phages [76,77] would likewise be not suitable for such isolation setups.

Higher adsorption of the more hydrophobic T4 than HS2 is in accordance with previous findings that hydrophobic phages (and other viruses) adsorb better to (bio-)surfaces than hydrophilic ones [40,42,43,47]. The hydrophobic surface of Viridibacillus sp. (composed of a unique S-layers with $40-60 \%$ hydrophobic amino acids [78]) exerted equally high attraction $(\approx 95 \%)$ to both T4 and HS2. Overall, our data on phage adsorption emphasized the role of hydrophobic interactions for the interaction between phages and bacterial surfaces [79]. However, high adsorption efficiencies did not necessarily lead to efficient co-transport. For instance, Viridibacillus sp., although showing $\approx 95 \%$ adsorption efficiency of HS2, was not isolated as a HS2 carrier on ZoBell medium. We speculate that the high salinity of ZoBell medium selectively allowed (e.g., for Bacillus sp.) and hindered (e.g., for Viridibacillus sp.) the chemotaxis of HS2 co-transport bacteria. The faster adsorption of phages to Viridibacillus sp. than to their respective hosts might result from hydrophobic interaction [78] and/or the production of phage-adsorbing extracellular structures (e.g., $[16,20])$. As Viridibacillus sp. showed a strong adsorption of phages with differing surface hydrophobicity, future study of the cell surfaces of this strain may help to qualify it as a model bacteria for phage delivery in biotechnological applications.

\subsection{Relevance for Phage Ecology and Biotechnology}

Inter-microbial hitchhiking is a common strategy among soil microorganisms [39]. Although phage adsorption to environmental bacteria has been described by cultureindependent techniques $[20,21,27,28,80]$, few attempts have been made to isolate culturable bacteria able to co-transport phages. Using mycelia as pathways, we here isolated five typical soil bacteria $[81,82]$ that can efficiently co-transport phages. While Viridibacillus and Enterobacter isolated from soil are frequently reported to be stress-tolerant and able to promote plant growth $[83,84]$, their ability to co-transport phages may facilitate their invasion of and persistence in the rhizosphere. Dormant phages (i.e., prophages that 
are integrated into bacterial genomes) have been suggested to act as "bacterial weapons" (as reviewed by [22]). Although self-lysis to release phages can be a burden, prophage carrying bacteria are typically immune to their released phages and thus can trigger an epidemic among the susceptible competitors [82]. However, such competitors are normally restricted to strains of the same species [21]. Lytic phages interacting with non-host bacteria may further act as inter-species "weapons" for their bacterial carriers [10,20,21]. Hence, analyses on the ability of non-host bacteria to adsorb and transport phages may help to explain their environmental prevalence and become part of experimental phage ecology as e.g., recently proposed for testing new hypotheses of biological invasions [10]. Knowledge on phage-carrier bacteria will not only help to find novel non-host phage-carriers but also contribute to a better understanding of phage ecology and bacterial competition in natural and man-made environments. Non-host bacteria (i.e., Bacillus cereus) as phage carriers have been isolated and shown to facilitate phage invasion into biofilms and to mediate biofilm compositions in a (model) wastewater environment [20]. For water-unsaturated environments such as soil, phages usually get rapidly inactivated [85], which may hinder their anti-bacterial efficiency against unwanted biofilms (e.g., of plant pathogens). As phage adsorption to (bio-) surfaces [49,86] (e.g., with non-host bacteria $[10,21]$ ) is known to protect phages from inactivation, phage-carrying bacteria may also be used both to prolong phage infectivity and targeted phage delivery to biofilms in natural and man-made environments. For instance, Viridibacillus and Enterobacter sp. have been described as potential plantgrowth-promoting bacteria [83,84]. Being also identified as good phage carriers in this study, they may also be considered as candidates for phage delivery in soil to combat unwanted biofilms of plant and root pathogens. However, further refinement of the method may be needed, as any cultivation-based selection and isolation of bacteria will depend on the nutrient media used in the host bacteria lawn. As hyphal-riding bacteria are similarly found in other environments than soil, future work may allow isolating new phage carriers of high relevance in phage ecology and biotechnology from other natural and man-made environments. In addition, our easy and inexpensive isolation approach may also become helpful in the education field, representing a very good task for laboratory practical courses in viral ecology.

Supplementary Materials: The following supporting information can be downloaded at https: / / www.mdpi.com/article/10.3390/v14020195/s1. Extended protocol for microcosm assembly. Figure S1: Representative images of microcosms of control scenarios (i.e., PBS, T4/HS2, and P. putida KT2440) in experiments to validate the setups using gfp-labeled P. putida KT2440 as phage carrier. Figure S2. Representative images of microcosms of control scenarios (i.e., "sterile soil", "sterile soil + T4/HS2", and "fresh soil") in experiments to isolate soil bacteria able to co-transport phages. Figure S3. Representative fluorescent micrographs of dispersion of gfp-labeled P. putida KT2440 (i.e., without phages) along the hyphae after $18 \mathrm{~h}$ and colonization of gfp-labeled phage-carrying P. putida KT2440 on the outer host agar ring after 2 days. Table S1. Characteristics and colloidal stability of used model phages. Table S2. Time-dependent phage adsorption rate constant $(k)$ in experiments comparing phage adsorption efficiencies to host and to non-host Viridibacillus sp. Table S3. Overview of buffers and media used in this study.

Author Contributions: Conceptualization, X.Y. and L.Y.W.; methodology, X.Y. and R.K.; investigation, X.Y. and N.K.; data curation, X.Y. and N.K.; writing—original draft preparation, X.Y.; writing-review and editing, X.Y., R.K., H.H., A.C. and L.Y.W.; supervision, H.H., A.C. and L.Y.W. All authors have read and agreed to the published version of the manuscript.

Funding: This work was supported by the Collaborative Research Centre AquaDiva of the Friedrich Schiller University Jena, funded by the Deutsche Forschungsgemeinschaft (DFG, German Research Foundation)-SFB 1076-project number 218627073 and the Helmholtz Centre for Environmental Research-UFZ.

Institutional Review Board Statement: Not applicable.

Informed Consent Statement: Not applicable. 


\section{Data Availability Statement: Not applicable.}

Acknowledgments: The authors wish also to thank Maria Fabisch and Anke Hädrich for the great coordination of the CRC AquaDiva and iRTG AquaDiva and the Hainich CZE site manager Robert Lehmann for soil sampling.

Conflicts of Interest: The authors declare no conflict of interest.

\section{References}

1. Blazanin, M.; Turner, P.E. Community context matters for bacteria-phage ecology and evolution. ISME J. 2021, 15, 3119-3128. [CrossRef]

2. Gelman, D.; Yerushalmy, O.; Alkalay-Oren, S.; Rakov, C.; Ben-Porat, S.; Khalifa, L.; Adler, K.; Abdalrhman, M.; CoppenhagenGlazer, S.; Aslam, S.; et al. Clinical Phage Microbiology: A suggested framework and recommendations for the in-vitro matching steps of phage therapy. Lancet Microbe 2021, 2, e555-e563. [CrossRef]

3. Almeida, G.M.D.F.; Sundberg, L.-R. The forgotten tale of Brazilian phage therapy. Lancet Infect. Dis. 2020, 20, e90-e101. [CrossRef]

4. Gutiérrez, D.; Rodríguez-Rubio, L.; Martínez, B.; Rodríguez, A.; García, P. Bacteriophages as Weapons Against Bacterial Biofilms in the Food Industry. Front. Microbiol. 2016, 7, 825. [CrossRef]

5. Islam, M.R.; Martinez-Soto, C.E.; Lin, J.T.; Khursigara, C.M.; Barbut, S.; Anany, H. A systematic review from basics to omics on bacteriophage applications in poultry production and processing. Crit. Rev. Food Sci. Nutr. 2021, 1-33. [CrossRef]

6. Loponte, R.; Pagnini, U.; Iovane, G.; Pisanelli, G. Phage Therapy in Veterinary Medicine. Antibiotics 2021, 10, 421. [CrossRef]

7. Stachler, E.; Kull, A.; Julian, T.R.; McBain, A.J. Bacteriophage Treatment before Chemical Disinfection Can Enhance Removal of Plastic-Surface-Associated Pseudomonas aeruginosa. Appl. Environ. Microbiol. 2021, 87, e00980-21. [CrossRef] [PubMed]

8. Lee, K.L.; Hubbard, L.C.; Hern, S.; Yildiz, I.; Gratzl, M.; Steinmetz, N.F. Shape matters: The diffusion rates of TMV rods and CPMV icosahedrons in a spheroid model of extracellular matrix are distinct. Biomater. Sci. 2013, 1, 581-588. [CrossRef]

9. Dennehy, J.J. What Ecologists Can Tell Virologists. Annu. Rev. Microbiol. 2014, 68, 117-135. [CrossRef] [PubMed]

10. You, X.; Kallies, R.; Kühn, I.; Schmidt, M.; Harms, H.; Chatzinotas, A.; Wick, L.Y. Phage co-transport with hyphal-riding bacteria fuels bacterial invasion in a water-unsaturated microbial model ecosystem. ISME J. 2021. [CrossRef]

11. Dennehy, J.J.; Friedenberg, N.A.; Yang, Y.W.; Turner, P.E. Bacteriophage Migration via Nematode Vectors: Host-Parasite-Consumer Interactions in Laboratory Microcosms. Appl. Environ. Microbiol. 2006, 72, 1974-1979. [CrossRef]

12. Vacheron, J.; Heiman, C.M.; Keel, C. Live cell dynamics of production, explosive release and killing activity of phage tail-like weapons for Pseudomonas kin exclusion. Commun. Biol. 2021, 4, 87. [CrossRef] [PubMed]

13. Abedon, S.T. Ecology of Anti-Biofilm Agents II: Bacteriophage Exploitation and Biocontrol of Biofilm Bacteria. Pharmaceuticals 2015, 8, 559-589. [CrossRef] [PubMed]

14. Trubl, G.; Hyman, P.; Roux, S.; Abedon, S.T. Coming-of-Age Characterization of Soil Viruses: A User's Guide to Virus Isolation, Detection within Metagenomes, and Viromics. Soil Syst. 2020, 4, 23. [CrossRef]

15. Simmons, M.; Drescher, K.; Nadell, C.D.; Bucci, V. Phage mobility is a core determinant of phage-bacteria coexistence in biofilms. ISME J. 2018, 12, 531-543. [CrossRef] [PubMed]

16. Vidakovic, L.; Singh, P.K.; Hartmann, R.; Nadell, C.D.; Drescher, K. Dynamic biofilm architecture confers individual and collective mechanisms of viral protection. Nat. Microbiol. 2018, 3, 26-31. [CrossRef] [PubMed]

17. Lacroix-Gueu, P.; Briandet, R.; Lévêque-Fort, S.; Bellon-Fontaine, M.-N.; Fontaine-Aupart, M.-P. In situ measurements of viral particles diffusion inside mucoid biofilms. Comptes Rendus Biol. 2005, 328, 1065-1072. [CrossRef] [PubMed]

18. Gallet, R.; Shao, Y.; Wang, I.-N. High adsorption rate is detrimental to bacteriophage fitness in a biofilm-like environment. BMC Evol. Biol. 2009, 9, 241. [CrossRef]

19. Abedon, S.T. Phage "delay" towards enhancing bacterial escape from biofilms: A more comprehensive way of viewing resistance to bacteriophages. AIMS Microbiol. 2017, 3, 186. [CrossRef]

20. Yu, Z.; Schwarz, C.; Zhu, L.; Chen, L.; Shen, Y.; Yu, P. Hitchhiking Behavior in Bacteriophages Facilitates Phage Infection and Enhances Carrier Bacteria Colonization. Environ. Sci. Technol. 2020, 55, 2462-2472. [CrossRef]

21. Ratheesh, N.K.; Calderon, C.A.; Zdimal, A.M.; Shrivastava, A. Swarm-mediated phage transport disrupts a biofilm inherently protected from phage penetration. bioRxiv 2021. [CrossRef]

22. Granato, E.T.; Meiller-Legrand, T.A.; Foster, K.R. The Evolution and Ecology of Bacterial Warfare. Curr. Biol. 2019, 29 , R521-R537. [CrossRef] [PubMed]

23. Hulme, P.E.; Bacher, S.; Kenis, M.; Klotz, S.; Kühn, I.; Minchin, D.; Nentwig, W.; Olenin, S.; Panov, V.; Pergl, J.; et al. Grasping at the routes of biological invasions: A framework for integrating pathways into policy. J. Appl. Ecol. 2008, 45, 403-414. [CrossRef]

24. Liebhold, A.M.; Brockerhoff, E.G.; Garrett, L.J.; Parke, J.L.; Britton, K.O. Live plant imports: The major pathway for forest insect and pathogen invasions of the US. Front. Ecol. Environ. 2012, 10, 135-143. [CrossRef]

25. Foster, R.; Peeler, E.; Bojko, J.; Clark, P.F.; Morritt, D.; Roy, H.E.; Stebbing, P.; Tidbury, H.J.; Wood, L.E.; Bass, D. Pathogens co-transported with invasive non-native aquatic species: Implications for risk analysis and legislation. NeoBiota 2021, 69, 79-102. [CrossRef] 
26. Pyšek, P.; Bacher, S.; Kühn, I.; Novoa, A.; Catford, J.A.; Hulme, P.E.; Pergl, J.; Richardson, D.M.; Wilson, J.R.U.; Blackburn, T.M. MAcroecological Framework for Invasive Aliens (MAFIA): Disentangling large-scale context dependence in biological invasions. NeoBiota 2020, 62, 407-461. [CrossRef]

27. de Jonge, P.A.; von Meijenfeldt, F.A.B.; Costa, A.R.; Nobrega, F.L.; Brouns, S.J.J.; Dutilh, B.E. Adsorption Sequencing as a Rapid Method to Link Environmental Bacteriophages to Hosts. iScience 2020, 23, 101439. [CrossRef]

28. Guerrero-Ferreira, R.C.; Viollier, P.H.; Ely, B.; Poindexter, J.S.; Georgieva, M.; Jensen, G.J.; Wright, E.R. Alternative mechanism for bacteriophage adsorption to the motile bacterium Caulobacter crescentus. Proc. Natl. Acad. Sci. USA 2011, 108, $9963-9968$. [CrossRef] [PubMed]

29. Kohlmeier, S.; Smits, T.H.M.; Ford, R.M.; Keel, C.; Harms, H.; Wick, L.Y. Taking the Fungal Highway: Mobilization of PollutantDegrading Bacteria by Fungi. Environ. Sci. Technol. 2005, 39, 4640-4646. [CrossRef]

30. Yang, P.; van Elsas, J.D. Mechanisms and ecological implications of the movement of bacteria in soil. Appl. Soil Ecol. 2018, 129, 112-120. [CrossRef]

31. Simon, A.; Bindschedler, S.; Job, D.; Wick, L.Y.; Filippidou, S.; Kooli, W.M.; Verrecchia, E.P.; Junier, P. Exploiting the fungal highway: Development of a novel tool for the in situ isolation of bacteria migrating along fungal mycelium. FEMS Microbiol. Ecol. 2015, 91, fiv116. [CrossRef]

32. Deveau, A.; Bonito, G.; Uehling, J.; Paoletti, M.; Becker, M.; Bindschedler, S.; Hacquard, S.; Hervé, V.; Labbé, J.; Lastovetsky, O.A.; et al. Bacterial-fungal interactions: Ecology, mechanisms and challenges. FEMS Microbiol. Rev. 2018, 42, 335-352. [CrossRef] [PubMed]

33. Jansa, J.; Hodge, A. Swimming, gliding, or hyphal riding? On microbial migration along the arbuscular mycorrhizal hyphal highway and functional consequences thereof. New Phytol. 2021, 230, 14-16. [CrossRef]

34. Jung, B.; Park, J.; Kim, N.; Li, T.; Kim, S.; Bartley, L.E.; Kim, J.; Kim, I.; Kang, Y.; Yun, K.; et al. Cooperative interactions between seed-borne bacterial and air-borne fungal pathogens on rice. Nat. Commun. 2018, 9, 31. [CrossRef]

35. Zhang, Y.; Kastman, E.K.; Guasto, J.S.; Wolfe, B.E. Fungal networks shape dynamics of bacterial dispersal and community assembly in cheese rind microbiomes. Nat. Commun. 2018, 9, 336. [CrossRef]

36. Lee, K.; Kobayashi, N.; Watanabe, M.; Sugita-Konishi, Y.; Tsubone, H.; Kumagai, S.; Hara-Kudo, Y. Spread and change in stress resistance of Shiga toxin-producing Escherichia coli O157 on fungal colonies. Microb. Biotechnol. 2014, 7, 621-629. [CrossRef]

37. Schlecht, L.M.; Peters, B.M.; Krom, B.P.; Freiberg, J.A.; Hänsch, G.M.; Filler, S.G.; Jabra-Rizk, M.A.; Shirtliff, M.E. Systemic Staphylococcus aureus infection mediated by Candida albicans hyphal invasion of mucosal tissue. Microbiology 2015, 161, 168-181. [CrossRef]

38. Robe, P.; Nalin, R.; Capellano, C.; Vogel, T.M.; Simonet, P. Extraction of DNA from soil. Eur. J. Soil Biol. 2003, 39, 183-190. [CrossRef]

39. Muok, A.R.; Briegel, A. Intermicrobial Hitchhiking: How Nonmotile Microbes Leverage Communal Motility. Trends Microbiol. 2021, 29, 542-550. [CrossRef] [PubMed]

40. Ghanem, N.; Stanley, C.E.; Harms, H.; Chatzinotas, A.; Wick, L.Y. Mycelial Effects on Phage Retention during Transport in a Microfluidic Platform. Environ. Sci. Technol. 2019, 53, 11755-11763. [CrossRef] [PubMed]

41. Rosner, A.; Gutstein, R. Adsorption of actinophage Pal 6 to developing mycelium of Streptomyces albus. Can. J. Microbiol. 1981, 27, 254-257. [CrossRef]

42. Dika, C.; Ly-Chatain, M.H.; Francius, G.; Duval, J.F.L.; Gantzer, C. Non-DLVO adhesion of F-specific RNA bacteriophages to abiotic surfaces: Importance of surface roughness, hydrophobic and electrostatic interactions. Colloids Surfaces A Physicochem. Eng. Asp. 2013, 435, 178-187. [CrossRef]

43. Richter, Ł.; Księżarczyk, K.; Paszkowska, K.; Janczuk-Richter, M.; Niedziółka-Jönsson, J.; Gapiński, J.; Łoś, M.; Hołyst, R.; Paczesny, J. Adsorption of bacteriophages on polypropylene labware affects the reproducibility of phage research. Sci. Rep. 2021, 11, 7387. [CrossRef] [PubMed]

44. Dika, C.; Duval, J.F.L.; Francius, G.; Perrin, A.; Gantzer, C. Isoelectric point is an inadequate descriptor of MS2, Phi X 174 and PRD1 phages adhesion on abiotic surfaces. J. Colloid Interface Sci. 2015, 446, 327-334. [CrossRef] [PubMed]

45. Almeida, G.M.F.; Laanto, E.; Ashrafi, R.; Sundberg, L.-R. Bacteriophage Adherence to Mucus Mediates Preventive Protection against Pathogenic Bacteria. MBio 2019, 10, e01984-19. [CrossRef] [PubMed]

46. Bichet, M.C.; Chin, W.H.; Richards, W.; Lin, Y.-W.; Avellaneda-Franco, L.; Hernandez, C.A.; Oddo, A.; Chernyavskiy, O.; Hilsenstein, V.; Neild, A.; et al. Bacteriophage uptake by mammalian cell layers represents a potential sink that may impact phage therapy. iScience 2021, 24, 102287. [CrossRef] [PubMed]

47. Ghanem, N.; Kiesel, B.; Kallies, R.; Harms, H.; Chatzinotas, A.; Wick, L.Y. Marine Phages As Tracers: Effects of Size, Morphology, and Physico-Chemical Surface Properties on Transport in a Porous Medium. Environ. Sci. Technol. 2016, 50, 12816-12824. [CrossRef]

48. Sobsey, M.D.; Dean, C.H.; Knuckles, M.E.; Wagner, R.A. Interactions and Survival of Enteric Viruses in Soil Materials. Appl. Environ. Microbiol. 1980, 40, 92-101. [CrossRef]

49. Moore, R.S.; Taylor, D.H.; Sturman, L.S.; Reddy, M.M.; Fuhs, G.W. Poliovirus Adsorption by 34 Minerals and Soils. Appl. Environ. Microbiol. 1981, 42, 963-975. [CrossRef]

50. Howard-Varona, C.; Lindback, M.M.; Bastien, G.E.; Solonenko, N.; Zayed, A.A.; Jang, H.; Andreopoulos, B.; Brewer, H.M.; Glavina del Rio, T.; Adkins, J.N.; et al. Phage-specific metabolic reprogramming of virocells. ISME J. 2020, 14, 881-895. [CrossRef] 
51. You, X.; Kallies, R.; Hild, K.; Hildebrandt, A.; Harms, H.; Chatzinotas, A.; Wick, L.Y. Transport of marine tracer phage particles in soil. Sci. Total Environ. 2022, 814, 152704. [CrossRef]

52. Fortier, L.-C.; Moineau, S. Phage Production and Maintenance of Stocks, Including Expected Stock Lifetimes BT. In Bacteriophages: Methods and Protocols, Volume 1: Isolation, Characterization, and Interactions; Clokie, M.R.J., Kropinski, A.M., Eds.; Humana Press: Totowa, NJ, USA, 2009; pp. 203-219. ISBN 978-1-60327-164-6.

53. Kropinski, A.M.; Mazzocco, A.; Waddell, T.E.; Lingohr, E.; Johnson, R.P. Enumeration of Bacteriophages by Double Agar Overlay Plaque Assay BT. In Bacteriophages: Methods and Protocols, Volume 1: Isolation, Characterization, and Interactions; Clokie, M.R.J., Kropinski, A.M., Eds.; Humana Press: Totowa, NJ, USA, 2009; pp. 69-76. ISBN 978-1-60327-164-6.

54. Schamfuß, S.; Neu, T.R.; van der Meer, J.R.; Tecon, R.; Harms, H.; Wick, L.Y. Impact of mycelia on the accessibility of fluorene to PAH-degrading bacteria. Environ. Sci. Technol. 2013, 47, 6908-6915. [CrossRef]

55. Mazzocco, A.; Waddell, T.E.; Lingohr, E.; Johnson, R.P. Enumeration of Bacteriophages Using the Small Drop Plaque Assay System BT. In Bacteriophages: Methods and Protocols, Volume 1: Isolation, Characterization, and Interactions; Clokie, M.R.J., Kropinski, A.M., Eds.; Humana Press: Totowa, NJ, USA, 2009; pp. 81-85. ISBN 978-1-60327-164-6.

56. Worrich, A.; König, S.; Miltner, A.; Banitz, T.; Centler, F.; Frank, K.; Thullner, M.; Harms, H.; Kästner, M.; Wick, L.Y.; et al. Mycelium-Like Networks Increase Bacterial Dispersal, Growth, and Biodegradation in a Model Ecosystem at Various Water Potentials. Appl. Environ. Microbiol. 2016, 82, 2902-2908. [CrossRef]

57. Berthold, T.; Centler, F.; Hübschmann, T.; Remer, R.; Thullner, M.; Harms, H.; Wick, L.Y. Mycelia as a focal point for horizontal gene transfer among soil bacteria. Sci. Rep. 2016, 6, 36390. [CrossRef]

58. Dechesne, A.; Wang, G.; Gülez, G.; Or, D.; Smets, B.F. Hydration-controlled bacterial motility and dispersal on surfaces. Proc. Natl. Acad. Sci. USA 2010, 107, 14369-14372. [CrossRef]

59. Kutter, E. Phage Host Range and Efficiency of Plating. In Bacteriophages: Methods and Protocols, Volume 1: Isolation, Characterization, and Interactions; Clokie, M.R.J., Kropinski, A.M., Eds.; Humana Press: Totowa, NJ, USA, 2009; pp. 141-149. ISBN 978-1-60327-164-6.

60. Lane, D.J. 16S/23S rRNA sequencing. In Nucleic Acid Techniques in Bacterial Systematics; Stackebrandt, E., Goodfellow, M., Eds.; John Wiley \& Sons: New York, NY, USA, 1991; pp. 75-115.

61. Frank, J.A.; Reich, C.I.; Sharma, S.; Weisbaum, J.S.; Wilson, B.A.; Olsen, G.J. Critical Evaluation of Two Primers Commonly Used for Amplification of Bacterial 16S rRNA Genes. Appl. Environ. Microbiol. 2008, 74, 2461-2470. [CrossRef]

62. Zhang, Z.; Schwartz, S.; Wagner, L.; Miller, W. A Greedy Algorithm for Aligning DNA Sequences. J. Comput. Biol. 2000, 7, 203-214. [CrossRef]

63. Pruesse, E.; Peplies, J.; Glöckner, F.O. SINA: Accurate high-throughput multiple sequence alignment of ribosomal RNA genes. Bioinformatics 2012, 28, 1823-1829. [CrossRef]

64. Shan, Y.; Harms, H.; Wick, L.Y. Electric Field Effects on Bacterial Deposition and Transport in Porous Media. Environ. Sci. Technol. 2018, 52, 14294-14301. [CrossRef]

65. Rashid, M.H.; Kornberg, A. Inorganic polyphosphate is needed for swimming, swarming, and twitching motilities of Pseudomonas aeruginosa. Proc. Natl. Acad. Sci. USA 2000, 97, 4885-4890. [CrossRef]

66. Thanki, A.M.; Taylor-Joyce, G.; Dowah, A.; Yakubu Nale, J.; Malik, D.; Rebecca Jane Clokie, M. Unravelling the Links between Phage Adsorption and Successful Infection in Clostridium difficile. Viruses 2018, 10, 411. [CrossRef]

67. Otto, S.; Bruni, E.P.; Harms, H.; Wick, L.Y. Catch me if you can: Dispersal and foraging of Bdellovibrio bacteriovorus 109J along mycelia. ISME J. 2017, 11, 386-393. [CrossRef]

68. Krueger, A.P. The Sorption of bacteriophage by living and dead susceptible bacteria: I. equilibirum conditions. J. Gen. Physiol. 1931, 14, 493-516. [CrossRef]

69. Pratama, A.A.; van Elsas, J.D. Gene mobility in microbiomes of the mycosphere and mycorrhizosphere -role of plasmids and bacteriophages. FEMS Microbiol. Ecol. 2019, 95, fiz053. [CrossRef]

70. Frada, M.J.; Vardi, A. Algal viruses hitchhiking on zooplankton across phytoplankton blooms. Commun. Integr. Biol. 2015, 8 , e1029210. [CrossRef]

71. Chaudhry, W.; Lee, E.; Worthy, A.; Weiss, Z.; Grabowicz, M.; Vega, N.M.; Levin, B. Mucoidy, a general mechanism for maintaining lytic phage in populations of bacteria. bioRxiv 2019. [CrossRef]

72. Wagner, P.L.; Waldor, M.K. Bacteriophage Control of Bacterial Virulence. Infect. Immun. 2020, 70, 3985-3993. [CrossRef]

73. Erickson, A.K.; Jesudhasan, P.R.; Mayer, M.J.; Narbad, A.; Winter, S.E.; Pfeiffer, J.K. Bacteria Facilitate Enteric Virus Co-infection of Mammalian Cells and Promote Genetic Recombination. Cell Host Microbe 2018, 23, 77-88. [CrossRef]

74. Li, X.; Gonzalez, F.; Esteves, N.; Scharf, B.E.; Chen, J. Formation of phage lysis patterns and implications on co-propagation of phages and motile host bacteria. PLoS Comput. Biol. 2020, 16, e1007236. [CrossRef]

75. Furuno, S.; Remer, R.; Chatzinotas, A.; Harms, H.; Wick, L.Y. Use of mycelia as paths for the isolation of contaminant-degrading bacteria from soil. Microb. Biotechnol. 2012, 5, 142-148. [CrossRef]

76. Penner, J.C.; Ferreira, J.A.G.; Secor, P.R.; Sweere, J.M.; Birukova, M.K.; Joubert, L.-M.; Haagensen, J.A.J.; Garcia, O.; Malkovskiy, A.V.; Kaber, G.; et al. Pf4 bacteriophage produced by Pseudomonas aeruginosa inhibits Aspergillus fumigatus metabolism via iron sequestration. Microbiology 2016, 162, 1583-1594. [CrossRef] [PubMed]

77. Nazik, H.; Joubert, L.-M.; Secor, P.R.; Sweere, J.M.; Bollyky, P.L.; Sass, G.; Cegelski, L.; Stevens, D.A. Pseudomonas phage inhibition of Candida albicans. Microbiology 2017, 163, 1568-1577. [CrossRef] [PubMed] 
78. Suhr, M.; Lederer, F.L.; Günther, T.J.; Raff, J.; Pollmann, K. Characterization of Three Different Unusual S-Layer Proteins from Viridibacillus arvi JG-B58 That Exhibits Two Super-Imposed S-Layer Proteins. PLoS ONE 2016, 11, e0156785. [CrossRef] [PubMed]

79. van Voorthuizen, E.; Ashbolt, N.; Schäfer, A. Role of hydrophobic and electrostatic interactions for initial enteric virus retention by MF membranes. J. Memb. Sci. 2001, 194, 69-79. [CrossRef]

80. Tarafder, A.K.; von Kügelgen, A.; Mellul, A.J.; Schulze, U.; Aarts, D.G.A.L.; Bharat, T.A.M. Phage liquid crystalline droplets form occlusive sheaths that encapsulate and protect infectious rod-shaped bacteria. Proc. Natl. Acad. Sci. USA 2020, 117, 4724-4731. [CrossRef]

81. Geesink, P.; Tyc, O.; Küsel, K.; Taubert, M.; van de Velde, C.; Kumar, S.; Garbeva, P. Growth promotion and inhibition induced by interactions of groundwater bacteria. FEMS Microbiol. Ecol. 2018, 94, fiy164. [CrossRef]

82. Xenophontos, C.; Taubert, M.; Harpole, W.S.; Küsel, K. Phylogenetic and metabolic diversity have contrasting effects on the ecological functioning of bacterial communities. FEMS Microbiol. Ecol. 2021, 97, fiab017. [CrossRef]

83. Thakur, R.; Sharma, K.C.; Gulati, A.; Sud, R.K.; Gulati, A. Stress-Tolerant Viridibacillus arenosi Strain IHB B 7171 from Tea Rhizosphere as a Potential Broad-Spectrum Microbial Inoculant. Indian J. Microbiol. 2017, 57, 195-200. [CrossRef]

84. Guo, D.-J.; Singh, R.K.; Singh, P.; Li, D.-P.; Sharma, A.; Xing, Y.-X.; Song, X.-P.; Yang, L.-T.; Li, Y.-R. Complete Genome Sequence of Enterobacter roggenkampii ED5, a Nitrogen Fixing Plant Growth Promoting Endophytic Bacterium With Biocontrol and Stress Tolerance Properties, Isolated From Sugarcane Root. Front. Microbiol. 2020, 11, 2270. [CrossRef] [PubMed]

85. Yeager, J.G.; O'Brien, R.T. Enterovirus inactivation in soil. Appl. Environ. Microbiol. 1979, 38, 694-701. [CrossRef]

86. Chrysikopoulos, C.V.; Aravantinou, A.F. Virus inactivation in the presence of quartz sand under static and dynamic batch conditions at different temperatures. J. Hazard. Mater. 2012, 233-234, 148-157. [CrossRef] [PubMed] 